\title{
POSISI DAYA SAING DAN TINGKAT PERSAINGAN MINYAK ATSIRI INDONESIA DI PASAR GLOBAL
}

\author{
Nia Rosiana ${ }^{1}$, Feryanto ${ }^{1}$, dan Vela Rostwentivaivi Sinaga ${ }^{2}$ \\ ${ }^{1}$ Departemen Agribisnis, Fakultas Ekonomi dan Manajemen IPB \\ ${ }^{2}$ Fakultas Pertanian, Universitas Garut \\ Email: fery.william@gmail.com
}

\begin{abstract}
ABSTRAK
Permintaan minyak atsiri Indonesia dalam satu dekade terakhir, menunjukkan tren yang positif dalam memenuhi pasar global. Namun demikian, upaya untuk meningkatkan daya saing produk minyak atsiri mengalami fluktuatif. Berkaitan dengan hal tersebut, penelitian ini bertujuan untuk menganalisis posisi daya saing dan tingkat persaingan minyak atsiri Indonesia di pasar global. Metode analisis yang digunakan adalah dengan pendekatan RCA Dinamis dan analisis korelasi rank spearman, analisis menggunakan data time series (2001-2015). Sepanjang periode 2001-2015 Indonesia memiliki daya saing, cenderung memiliki tren positif bila dibandingkan dengan sembilan negara eksportir utama lainnya. Hasil RCA Dinamis menunjukkan bahwa produk minyak Atsiri Indonesia periode 2001-2005 masuk kategori leading retreat, sedangkan periode 2005-2010 dan 2011-2015 masuk kategori rising star, yakni produk yang memiliki potensi untuk dikembangkan menjadi komoditas unggulan ekspor Indonesia. Namun demikian korelasi rank spearman menunjukkan bahwa tidak ada hubungan yang signifikan antara daya saing minyak atsiri Indonesia dengan sembilan negara eksportir utama lainnya.
\end{abstract}

Kata kunci: daya saing, minyak atsiri, pasar global

\begin{abstract}
Indonesian essential oil demand in the last decade, showed a positive trend in global markets. However, efforts to improve product competitiveness experienced volatile essential oil. This study aimed to analyze the competitive position and the level of competition Indonesian essential oil in the global market. The analytical method used is the Dynamic RCA approach and Spearman rank correlation analysis, analysis of data using time series (2001-2015). Throughout the 2001-2015 periods Indonesia has a competitive advantage, tend to have a positive trend when compared with nine other major exporting countries. Dynamic RCA results showed that the essential oils products Indonesia 2001-2005 period were leading retreat categories, while the period of 2005-2010 and 2011-2015 in the category of Rising Star, which is a product that has the potential to be developed into the leading commodity exports of Indonesia. However, Spearman rank correlation showed that no significant relationship between the competitiveness of Indonesian essential oil with nine other major exporting countries.
\end{abstract}

Keywords: competitiveness, essential oil, global market

\section{PENDAHULUAN}

Indonesia merupakan salah satu negara yang memiliki sekitar 40 jenis tanaman penghasil minyak atsiri dan sekitar 12 jenis telah digunakan sebagai sumber minyak atsiri komersial (Dewan Atsiri Indonesia, 2017; Kementerian Perdagangan Republik Indonesia, 2014). Beberapa jenis tanaman sebagai penghasil minyak atsiri yang dikenal di Indonesia, diantaranya akar wangi, nilam, sereh wangi, cengkeh, pala, kayu manis, dan lain sebagainya. Minyak nilam memiliki mutu terbaik dalam pasar essential oil dunia dan Indonesia menguasai $80-90$ persen pangsa pasar perdagangan minyak nilam (Kementrian Perdagangan Republik Indonesia 2014). Indonesia dikenal sebagai negara produsen dan pengekspor minyak atsiri terbesar di dalam perdagangan dunia dengan negara pesaing seperti China, India dan Brazil. Berdasarkan data International Trade Centre (ITC), nilai ekspor minyak atsiri mencapai USD 91 juta (2009) dan meningkat menjadi USD 161 juta (2011). Tahun 2013 nilai ekspor 
minyak atsiri Indonesia turun menjadi USD 123 juta dan menjadikan Indonesia peringkat ke-9 sebagai ekportir terbesar dunia.

Berkembangnya minyak atsiri di Indonesia didukung dengan permintaan pasar dunia yang semakin meningkat. Peluang pasar Indonesia masih terbuka luas khususnya pasar Eropa dan Amerika. Minyak atsiri dibutuhkan sebagai bahan baku industri parfum, kosmetik, kesehatan, hingga makanan. ITC mencatat nilai ekspor Indonesia tahun 2013 mencapai 9.67 juta USD. Nilai ini masih kalah bila dibandingkan dengan Negara Brazil, India, Amerika Serikat, Perancis, China, dan Italia. Melihat kondisi tersebut dikatakan bahwa Indonesia memiliki keunggulan kompetitif dan komparatif minyak atsiri.

Beberapa penelitian terkait daya saing minyak atsiri, diantaranya Muchtaridi (2005); Yuhono dan Suhirman (2006); Yuhono (2008); Sari dan Hartono (2010); Efendi et al., (2014); Adiwijaya dan Malika (2016). Daya saing ekspor dapat diukur dengan indikator Revealed Comparative Advantage (RCA) dan Acceleration Ratio (AR). Penelitian Sari dan Hartono (2010) menjelaskan kinerja ekspor minyak nilam Indonesia memiliki tren ekpor positif, Indeks Spesialisasi Perdagangan (ISP) positif, Indeks Penetrasi Pasar (IPP) rata-rata terbesar. Daya saing ekspor minyak nilai kuat dengan nilai RCA rata-rata terbesar dengan nilai AR mendekati +1 serta kemampuan percepatan ekspor baik. Adapun faktor-faktor yang berpengaruh nyata terhadap pemintaan ekspor minyak nilam adalah harga internasional dan harga ditingkat penyuling. Penelitian Efendi et al., (2014) menerangkan tingkat daya saing diukur menggunakan ISP dan Indonesia berada di urutan kedua setelah Argentina dengan perkembangan ISP berkisar 0.63-0.73 dan cenderung menurun rata-rata 1.45 persen per tahun. Kondisi ini selaras dengan penelitian Adiwijaya dan Malika (2016) yang menjelaskan rendahnya produktivitas dan mutu minyak atsiri disebabkan rendahnya mutu genetik tanaman, teknologi budidaya yang sederhana, serta proses pascapanen yang belum tepat.

Sehingga dengan demikian, semakin tinggi permintaan minyak atsiri Indonesia dan ketatnya persaingan antar negara produsen, menunjukkan bahwa minyak atsiri dunia memiliki potensi untuk dikembangkan. Peningkatan daya saing dan produk minyak atsiri dengan melihat perkembangan pasar dunia menjadi suatu keharusan. Namun demikian, upaya untuk meningkatkan daya saing produk minyak atsiri mengalami fluktuatif. Berkaitan dengan hal tersebut, penelitian ini bertujuan untuk menganalisis posisi daya saing dan tingkat persaingan minyak atsiri Indonesia di pasar global.

\section{METODE PENELITIAN}

Data yang digunakan dalam mengukur daya saing minyak atisiri Indonesia dengan 9 negara (China, USA, India, Perancis, Brasil, UK, Argentina, Jerman, dan Meksiko) utama eksportir atsiri dunia menggunakan data time series (2001-2015). Minyak Atsiri yang menjadi objek penelitian ini merupakan gabungan minyak atsiri atau yang dikenal dengan nama essential oil secara keseluruhan (nilam, sereh, akar wangi dan lainnya), dengan kode kelompok HS-3301. Data yang digunakan adalah data sekunder dengan sumber dari United Nation Comtrade dan International Trade Center.

Indikator untuk mengukur suatu komoditi banyak dikembangkan $(\mathrm{Ng}, 2002$, World Bank Insitut), salah satunya adalah RCA (Revealed Competitiveness Advantage, 2010). RCA digunakan untuk mengukur daya saing dengan menggunakan data ekspor dan impor komoditi atau negara yang menjadi objek penelitian (Balassa, 1965; Bowen, 1983). Namun demikian untuk mengetahui daya saing produk minyak atsiri oleh 10 eksportir utama dunia, akan menggunakan RCA dinamis. RCA dinamis merupakan modifikasi dari RCA statis yang masih jarang digunakan dalam penelitian daya saing. Metode RCA dinamis diperkenalkan oleh Edwards dan Schoer (2001) pada penelitiannya di Afrika Selatan untuk melihat struktur dan daya saing dari perdagangan. Metode RCA dinamis memiliki keuntungan, diantaranya mampu mendekripsikan RCA dengan tepat dan dapat menentukan kedudukan produk dalam negara-negara tujuan ekspor (Widyasanti, 2010). RCA dinamis secara matematika dapat dituliskan sebagai berikut;

$D R C A_{j}=\frac{\Delta R C A_{j}}{R C A_{j}}=\frac{\Delta\left(X_{i j} / \sum_{j} X_{i j}\right)}{\left(X_{i j} / \sum_{j} X_{i j}\right)}-\frac{\Delta\left(X_{w j} / \sum_{j} X_{w j}\right)}{\left(X_{w j} / \Sigma_{j} X_{w j}\right)}$

dimana,

$\mathrm{RCA}_{\mathrm{j}} \quad$ : Indeks daya saing komoditi j dari negara $\mathrm{i}$ 
$\mathrm{X}_{\mathrm{ij}} \quad$ : Ekspor negara untuk komoditi $\mathrm{j}$

$\mathrm{X}_{\mathrm{i}} \quad$ : Total ekspor negara $\mathrm{i}$

$\mathrm{X}_{\mathrm{wj}} \quad$ : Ekspor dunia untuk komoditi $\mathrm{j}$

$\mathrm{X}_{\mathrm{w}} \quad$ : Total ekspor dunia

Hasil indeks RCA dinamis tersebut, kemudian dipetakan dalam matriks untuk mempermudah menganalisis hasil yang diperoleh (Edwards dan Schoer, 2001). Matriks penempatan daya saing ekspor minyak atsiri dapat dilihat pada Tabel 1 berikut,

Tabel 1.

Matriks Penempatan Daya Saing Ekspor.

\begin{tabular}{|c|c|c|c|c|}
\hline & $\begin{array}{l}\text { Pangsa j } \\
\text { pada } \\
\text { ekspor } \\
\text { negara }\end{array}$ & & $\begin{array}{l}\text { Pangsa j } \\
\text { pada } \\
\text { ekspor } \\
\text { pasar dunia }\end{array}$ & Posisi \\
\hline \multirow{3}{*}{$\begin{array}{l}\text { RCA } \\
\text { Naik }\end{array}$} & Naik & $>$ & Naik & Rising Stars \\
\hline & Naik & $>$ & Turun & Falling Stars \\
\hline & Turun & $>$ & Turun & Lagging Retreat \\
\hline & Turun & < & Naik & LostOpportunity \\
\hline $\mathrm{RCA}$ & Turun & $<$ & Turun & Leading Retreat \\
\hline Turun & Naik & $<$ & Naik & $\begin{array}{l}\text { Lagging } \\
\text { Opportunity }\end{array}$ \\
\hline
\end{tabular}

Sementara analisis rank spearman dilakukan untuk melihat dan mengukur hubungan daya saing Indonesia terhadap sembilan negara utama eksportir lainnya.

\section{HASIL DAN PEMBAHASAN}

Indonesia bersama beberapa negara Asia, Eropa dan Amerika lainnya merupakan salah satu eksportir utama komoditas minyak atsiri dunia. Namun dalam perkembangannya, posisi daya saing ekspor minyak astiri Indonesia berfluktuatif. Beradasarkan data dari UN Comtraede (2017), pangsa pasar minyak atsiri Indonesia di pasar dunia hanya sebesar 3.7 persen, jahu dibawah China (16.4 persen) dan USA (12.3 persen). Namun demikian daya saing minyak atsiri Indonesia, masih relatif lebih baik bila dibandingkan dengan daya saing ekspor minyak atsiri China dan USA yang menguasai pasar dunia.

Pada Tabel 2, dijelaskan bahwa daya saing ekspor minyak atsiri Indonesia selama 3 periode mengalami fluktuasi, dan periode 20112015 lebih rendah bila dibandingkan periode 2001-2005 dan 2006-2010. Hal ini dikarenakan, minyak atsiri Indonesia didominiasi minyak nilam, sereh dan akar wangi yang permintaannya relatif berfluktuatif. Daya saing ekspor minyak atsiri Indonesia, hanya kalah bersaing dengan Argentina, India, dan Brasil. Namun demikian, hampir semua negara eksportir minyak atsiri dunia mengalami penurunan daya saing selama tiga periode tersebut, kecuali Jerman dan Meksiko yang memiliki kecenderungan memiliki tren peningkatan. China sebagai pemilik pangsa pasar terbesar pada tahun 2015, hampir tidak memiliki daya saing bila dibandingkan dengan negara-negara eksportir utama lainnya. Namun, kuantitas besar dan kontinuitas yang terjamin, menyebabkan konsumen dunia tetap membeli minyak atsiri ke negara ini.

Tabel 2.

Tingkat Daya Saing Minyak Atsiri Negara Eksportir Utama Dunia.

\begin{tabular}{lllll}
\hline \multirow{2}{*}{ No } & Negara & \multicolumn{3}{l}{ Rata-Rata RCA } \\
\cline { 3 - 5 } & & $\begin{array}{l}2001- \\
2005\end{array}$ & $2005-2010$ & $\begin{array}{l}2011- \\
2015\end{array}$ \\
\hline $\mathbf{1}$ & China & 0.8 & 0.6 & 0.8 \\
$\mathbf{2}$ & USA & 2.0 & 1.9 & 1.5 \\
$\mathbf{3}$ & India & 6.7 & 9.6 & 9.4 \\
$\mathbf{4}$ & Perancis & 2.5 & 2.7 & 2.5 \\
$\mathbf{5}$ & Brasil & 5.5 & 4.7 & 4.6 \\
$\mathbf{6}$ & UK & 1.6 & 1.8 & 2.0 \\
$\mathbf{7}$ & Argentina & 10.4 & 11.2 & 10.6 \\
$\mathbf{8}$ & Indonesia & 3.9 & 4.6 & 3.7 \\
$\mathbf{9}$ & Jerman & 0.3 & 0.4 & 0.5 \\
$\mathbf{1 0}$ & Meksiko & 0.9 & 1.2 & 1.2 \\
\hline
\end{tabular}

Minyak atsiri (HS-3301) Indonesia, memiliki daya saing yang sangat baik dibuktikan dengan nilai RCA > 1 , ini mengindikasikan bahwa minyak atsiri memiliki prospek untuk dikembangkan sebagai komoditas ekspor yang belum digarap secara optimal. Selama periode 2001-2015 (15 tahun) dengan membagi tiga periode akan dipetakan daya saing kelompok produk minyak atsiri Indonesia ada dimana berdasarkan pertumbuhan pangsa pasarnya dengan pendekatan RCA dinamis (Edwards dan Schoer, 2001).

Berdasarkan hasil analisis pemetaan daya saing minyak atsiri seperti yang disajikan pada Gambar 1, menunjukkan selama tiga periode (2001-2005, 2006-2010, dan 20112015) peta daya saing minyak atisiri Indonesia mengalami perubahan. Posisi daya saing minyak atsiri Indonesia di pasar dunia pada periode 2001-2005 berada pada kuadran leading retreat, artinya pada kondisi ini minyak atsiri Indonesia mengalami penurunan daya saing. Dimana pertumbuhan pangsa pasar Indonesia dan dunia sama-sama mengalami 
penurunan. Tercatat bahwa pertumbuhan pangsa pasar Indonesia mengalami penurunan 21.98 persen dan pasar dunia juga mengalami penurunan sebesar 19.03 persen untuk minyak atsiri Indonesia. Hal ini diduga akibat produksi yang tidak stabil, karena kombinasi cuaca yang tidak mendukung dan harga minyak atisiri yang tidak berflutktuatif pada periode tersebut (Minyak Atisiri Indonesia, 2017). Walaupun harga relatif stabil, namun produksi dengan kualitas minyak atsiri Indonesia yang dihasilkan tidak sebaik negara pesaing utama lainnya, rendahnya perhatian dari instansi terkait dan fluktuasi harga di tingkat pengrajin sehingga minat pengrajin menjadi berkurang dan beralih pada usaha lain (Yuhono dan Suhirman, 2006). Sehigga dengan demikian pangsa pasarnya tidak kompetitif, perubahan yang dinamis menyebabkan mengalihkan permintaan kepada negara-negara seperti India, China, dan Brasil.

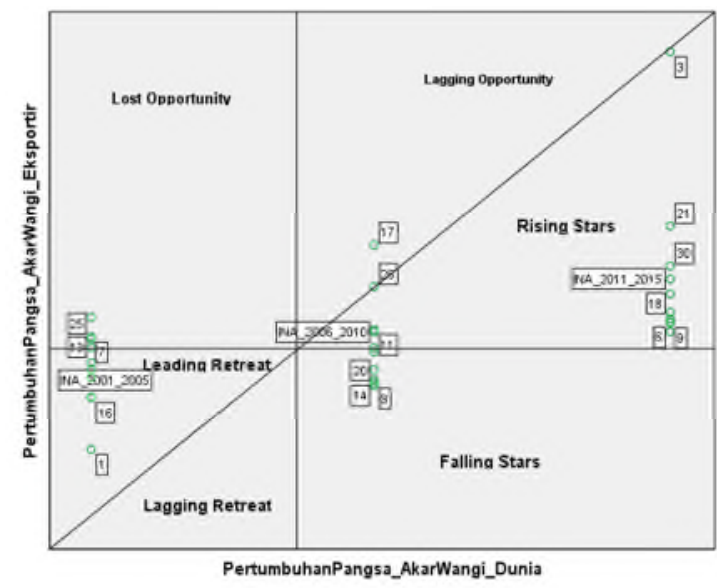

Gambar 1

Peta Daya Saing Minyak Atsiri Negara Eksportir Utama Dunia

Pada periode 2006-2010 terjadi perubahan yang dinamis posisi daya saing minyak atsiri Indonesia, yakni adanya kenaikan daya saing dan pangsa pasar yang lebih kompetitif. Hal ini dapat dilihat dari posisi minyak atsiri Indonesia terhadap pemain utama lainnya berada pada kuadran rising stars. Pada periode ini terjadi peningkatan pertumbuhan pangsa pasar minyak atsiri Indonesia yakni sebesar 18.35 persen lebih tinggi dari pertumbuhan pangsa pasar dunia yang hanya sebesar 14.06 persen. Kondisi ini terus berlangsung sampai periode lima tahun terakhir (2011-2015), posisi daya saing minyak atsiri Indonesia ada pada kuadran rising stars. Namun pada periode ini pertumbuhan pangsa pasar minyak atsiri Indonesia jauh lebih besar yakni 51.29 persen, sedangkan pertumbuhan pangsa pasar minyak atsiri dunia sebesar 48.66 persen. Hal ini didukung kemudahan ekspor dan harga yang cenderung meningkat, sehingga memberikan isentif bagi produsen minyak atsiri di dalam negeri.

Pesaing utama Indonesia, untuk minyak atsiri adalah China, USA, India, Perancis, Brasil, UK, dan Argentina. Beberapa negara ini juga menjadi pengolah minyak atsiri untuk produk kosmetika. Beberapa negara tersebut pada tahun 2011-2015 memiliki posisi rising stars (China, Argentina, Meksiko), namun negara lain berada pada posisi yang mengalami penurunan daya saing (USA, India, Perancis, dan Brasil). Pada periode 2006-2010 dan 2011-2015 dengan perubahan yang dinamis, maka produk minyak atsiri, dapat dikembangkan dan dioptimalkan sebagai komoditas ekspor, untuk mengisi pasar dunia dari pesaing utama yang mengalami penurunan daya saing. Namun, tantangan ini harus didukung dengan perbaikan kualitas dan jaminan kontinuitas jumlah dari produsen dalam negeri (Ningsih, 2013; Sari dan Hartono, 2010). Momentum kenaikan daya saing minyak atsiri Indonesia harus dimanfaatkan, dengan meningkatkan kualitas dan akses ekspor ke nengara-negara pengolah minyak atsiri Indonesia. Posisi minyak atsiri Indonesia yang berada pada rising stars selama satu dekade menunjukkan bahwa minyak atsiri Indonesia sangat diminati pasar dunia.

Tabel 3.

Korelasi Daya Saing Antar Negara Eksportir Minyak Atsiri Dunia

\begin{tabular}{|c|c|c|c|c|c|c|}
\hline & & $\mathrm{CHN}$ & USA & INA & FRA & BRZL \\
\hline \multirow{4}{*}{ IDN } & $\begin{array}{l}\text { Correlation } \\
\text { Coefficient }\end{array}$ & -0.27 & 0.269 & -0.023 & 0.171 & -0.243 \\
\hline & Sig. (2-tailed) & 0.326 & 0.333 & 0.934 & 0.543 & 0.382 \\
\hline & $\mathrm{N}$ & 15 & 15 & 15 & 15 & 15 \\
\hline & & UK & ARG & IDN & GER & MEX \\
\hline \multirow{3}{*}{ IDN } & $\begin{array}{l}\text { Correlation } \\
\text { Coefficient }\end{array}$ & -0.21 & 0.305 & 1 & -0.017 & 0.346 \\
\hline & Sig. (2-tailed) & 0.446 & 0.27 & & 0.952 & 0.207 \\
\hline & $\mathrm{N}$ & 15 & 15 & 15 & 15 & 15 \\
\hline
\end{tabular}

Dinamika perubahan terhadap posisi peta daya saing minyak atsiri Indonesia dengan negara pesaing utama (eksportir) dunia berdasarkan hasil analisis dengan menggunakan rank spearman, secara umum tidak terdapat hubungan yang signifikan 
terhadap negara-negara eksportir utama. Hal ini ditunjukkan dari nilai $p$-value yang lebih besar dari taraf nyata 0.1 (Tabel 3). Hal ini dikarenakan pasar yang dituju oleh masingmasing negara memiliki perbedaan. Indonesia mengekspor minyak atsiri ke pasar Australia, Eropa, Jepang dan sebagian Amerika Serikat. Walaupun tidak terdapat hubungan yang signifikan antara pasar minyak atsiri Indonesia dengan negara-negara eksportir dunia lainnya, bukan berarti persaingan tidak terjadi.

Persaingan tetap terjadi, karena negara-negara pesaing utama lainnya, berupaya membuka pasar yang sudah ada, atau pasar Indonesia. Hal ini harus diantisipasi dengan memanfaatkan segala informasi perdagangan melalui kantor-kantor perwakilan dagang Indonesia di luar negeri.

\section{KESIMPULAN}

Minyak Atsiri Indonesia selama periode 2001-2015 memiliki daya saing dan diminati pasar dunia. Perkembangan dinamis daya saing minyak atsiri Indonesia, menunjukkan perbaikan peta yang kompetitif di pasar dunia. Periode 2001-2005 menunjukkan peta daya saing minyak atsiri Indonesia terhadap pasar dunia berada pada kuadran leading retreat, dan periode 2006-2010 dan 2011-2015 mengalami kenaikan yang sangat besar ditunjukkan terhadap kenaikan pertumbuhan pangsa pasar ekspor Indonesia dan dunia untuk minyak atsiri Indonesia (berada pada kuadran rising stars).

Hal ini membuktikan bahwa produk Indonesia mampu bersaing dan dapat membuka pasar minyak atsiri Indonesia di dunia. Indonesia dan eksportir utama dunia lainnya, tidak memiliki korelasi yang saling mempengaruhi terhadap daya saing minyak atsiri, dikarenakan adanya perbedaan pasar tujuan. Namun demikian produsen dan pemerintah perlu melakukan perbaikanperbaikan untuk mengoptimalkan kesempatan seperti peningkatan kualitas, kontinuitas, dan kemudahan izin ekspor agar daya saing minyak atsiri dapat dipertahankan.

\section{DAFTAR PUSTAKA}

Adiwijaya J.C, Malika U.E. 2016. Kelayakan Usaha Penyulingan Minyak Atsiri
Berdasarkan Aspek Finansial Dan Teknologi. Jurnal Ilmiah Inovasi. Vol 1 (3): 187-192.

Dewan Atsiri Indonesia. 2017. https://minyakatsiriindonesia.wordpress. com/atsiri/ (Diakses 15 Juni 2017).

Edwards, Lawrence and Volker Schoer. 2002. Measures of competitiveness: a dynamic approach to South Africa's trade performance in the 1990s. The South African Journal of Economics Vol (70): 1008-1046.

Efendi, Fauzi A.M. Machfud, dan Sukardi. 2014. Rancang Bangun Sistem Peningkatan Kinerja Rantai Pasok Industri Minyak Atsiri. Jurnal Manajemen Teknologi. Vol 13 (2): 126-153

Kementerian Perdagangan Republik Indonesia. 2014. Market Brief 2014 Minyak Atsiri. Atase Perdagangan KBRI Berlin.

Muchtaridi. 2006. Penelitian Pengembangan Minyak Atsiri Sebagai Aromaterapi Dan Potensinya Sebagai Produk Sediaan Farmasi. Jurnal Teknik Industri Pertanian. Vol 17 (3): 80-88.

Ningsih, Altika. 2013. Analisis Daya Saing dan Faktor-Faktor yang Memengaruhi Permintaan Mintak Atsiri Indonesia di Negara Tujuan Ekspor. Skripsi. Departemen Ilmu Ekonomi, FEM IPB. Bogor.

Sari P.N, Hartono S. 2010. Analisis Dinamika Ekspor Minyak Nilam Indonesia Ke Amerika Serikat. Agro Ekonomi. Vol 17 (1): 19-23.

Widyasanti, Amalia Adininggar. 2010. Perdagangan bebas regional dan daya saing ekspor: kasus Indonesia. Buletin Ekonomi Moneter dan Perbankan Vol (Juli): 5-22.

Yuhono J.T. 2012. Analisis Pendapatan Dan Daya Saing Usahatani Akar Wangi Di Kabupaten Garut. Buletin Littro. Vol XIX (2): 197-215.

Yuhono J.T, Suhirman S. 2006. Status Pengusahaan Minyak Atsiri Dan FaktorFaktor Teknologi Pasca Panen Yang Menyebabkan Rendahnya Rendemen Minyak. Bul. Littro. Vol 17 (2): 79-90. 